\title{
Determinants of Preeclampsia Among Pregnant Women in Chiro Referral Hospital, Oromia Regional State, Ethiopia: Unmatched Case- Control Study
}

\author{
Fikre Hambamo Katore \\ Abenet Menene Gurara $\mathbb{D D}^{2}$ \\ Teresa Kisi Beyen (D) ${ }^{3}$ \\ 'Department of Maternal and Child \\ Health, Mieso Woreda Health Bureau, \\ Mieso Town, Oromia Regional State, \\ Ethiopia; ${ }^{2}$ Department of Nursing, Arsi \\ University, Asella, Oromia Regional State, \\ Ethiopia; ${ }^{3}$ Department of Public Health, \\ Arsi University, Asella, Oromia Regional \\ State, Ethiopia
}

Background: Preeclampsia causes striking maternal, fetal, and neonatal mortality and morbidity both in developed and developing countries. However, evidence of risk factors of preeclampsia is limited in the study area.

Objective: To identify determinants of preeclampsia among pregnant women attending antenatal care services in Ciro Referral Hospital, Ethiopia, 2020.

Methods: A facility-based unmatched case-control study was conducted from July 1 to July 30, 2020, in Chiro Referral Hospital on a sample size of 306 (ie, 76 cases and 230 controls; with a 1:3 ratio). Data were coded and entered into Epi Info version 7 and then exported to SPSS version 21 for analysis. The odds ratio was calculated with $95 \%$ confidence intervals to show the strength of association and $p$-value $<0.05$ was used to declare statistical significance.

Results: A total of 302 ( 75 cases and 227 controls) pregnant mothers were interviewed with a response rate of $98.7 \%$. Being in the age group $\geq 35$ years $(\mathrm{AOR}=4.00 ; 95 \% \mathrm{CI}=1.25$ $12.80)$, rural residence $(\mathrm{AOR}=3.30 ; 95 \% \mathrm{CI}=1.50-7.26)$, having a family history of hypertension $(\mathrm{AOR}=3.25 ; 95 \% \mathrm{CI}=1.36-7.73)$, and being primigravida $(\mathrm{AOR}=3.71 ; 95 \%$ $\mathrm{CI}=1.49-9.22)$ were identified as risk factors for preeclampsia. However, consuming fruits more than 2-4 times per a week in their diet $(\mathrm{AOR}=0.38 ; 95 \% \mathrm{CI}=0.15-0.98)$ was a protective predictor of preeclampsia.

Conclusion: Maternal age, residence, family history of hypertension, gravida, and frequency of fruit consumption were identified determinants of preeclampsia. Thus, healthcare providers should give emphasis for pregnant mothers in the older age category, primigravida, those who have a history of a family with hypertension, and those from a rural residence to diagnose the diseases as early as possible. Additionally, advising pregnant mothers attending antenatal care to consume fruits as early as possible in their daily diet reduces the risk of preeclampsia.

Keywords: preeclampsia, determinants of preeclampsia, Ethiopia

\section{Introduction}

Worldwide, hypertensive disorders of pregnancy account for nearly $18 \%$ of all maternal deaths ${ }^{1}$ and are a risk for the baby. ${ }^{2}$ Preeclampsia and eclampsia, the common hypertensive disorders, occur in $6-10 \%$ of all pregnancies worldwide, ${ }^{3}$ and with a wide variation across regions. ${ }^{1}$ Preeclampsia is pregnancy-related hypertension that occurs after 20 weeks of gestation in a woman with previously
Correspondence: Abenet Menene Gurara Tel +251 912820585

Email abenetmen@gmail.com 
normal blood pressure and normally resolves within 12 weeks postpartum. ${ }^{4}$ It is typically characterized by the presence of high blood pressure reading greater than or equal to $140 / 90 \mathrm{mmHg}$ or a significant increment change in one or both pressures after 20 weeks gestation, the presence of protein in the urine, oedematous, and others in case of complications. Eclampsia was characterized by new-onset grand mal seizures in a woman with preeclampsia. ${ }^{3,4}$

Preeclampsia is of global public health importance and the most common medical threat in both developed and developing countries contributing to maternal and perinatal morbidity and mortality. ${ }^{2,5}$ It's one major direct cause is maternal mortality and neonatal adverse outcome. ${ }^{6,7}$ The overall prevalence of preeclampsia in developing countries ranges from $1.8 \%$ to $19.4 \%{ }^{7,8}$

The influence of preeclampsia on preterm birth was substantial. About $8-10 \%$ of women in their first pregnancy will give birth before 34 weeks as a consequence of preeclampsia. ${ }^{2}$ In Ethiopia, according to the Ethiopian Demographic Health survey 2016 report, hypertensive disorder during pregnancy contributes about $19 \%$ of maternal deaths. ${ }^{9}$ A review study in Ethiopia showed that the proportion of maternal mortality due to hypertensive disorders was increased from $4-29 \%$ at different health facilities between 1980 and $2012 .{ }^{10}$ A retrospective study conducted in Mettu Karl Hospital, Ethiopia reported a 2.4\% prevalence of pregnancy-induced hypertension (PIH), 12\% of adverse outcome of neonates, $10.2 \%$ of stillbirths, $30.5 \%$ of low birth weight, and $31.4 \%$ of preterm delivery. ${ }^{11}$

Several studies revealed that different factors threw in the determinants of preeclampsia among pregnant women from country to country as well as from place to place. Secondary analysis from the World Health Organization among 29 countries identified that maternal age, lack of formal education, chronic hypertension, renal and hepatic disease, anemia, sepsis, parity, and gravida/number pregnancies are determinants of preeclampsia. ${ }^{1}$ The study from Kombolcha, Ethiopia revealed that maternal education status and previous history of preeclampsia are risk factors for the occurrence of preeclampsia. ${ }^{12}$ Whereas a study on pregnant mothers of the Tigray region, Ethiopia showed that rural residence, less fruit consumption, multiple pregnancies, presence of gestational diabetes mellitus, and prepregnancy overweight were identified as independent risk factors for preeclampsia. ${ }^{13}$
The majority of deaths due to preeclampsia or eclampsia are avoidable through the provision of timely and effective care to the women presenting with the complications. Improving healthcare to prevent and treat women with hypertensive disorders is a necessary step towards reducing maternal and infant mortality and morbidity. ${ }^{14}$

To intervene in adverse outcomes of maternal pregnancy-induced hypertension, the World Health Organization recommends low dose aspirin, calcium supplementation, and guidelines for prevention and treatment of pregnancy-induced hypertension by magnesium sulfate, and Ethiopia has adapted this treatment protocol and routine screening of hypertensive disorders of pregnancy during antenatal care visits. ${ }^{14-16}$

Investigating the determinants of preeclampsia was an important way to overcome the potential causes of hypertensive disorders during pregnancy, particularly for preeclampsia. In 2019, the six months report showed the magnitude of preeclampsia in the Chiro Referral Hospital was about 850 per 10,000 mothers. Thus, in an area with such a high rate, forecasting the determinants are very crucial to prevent the occurrence of the disease. This study aimed to investigate the determinants of preeclampsia among pregnant women attending antenatal care services in the Chiro Referral Hospital, Oromia Regional State, Ethiopia.

\section{Methods and Materials Study Area and Period}

The study was conducted in Chiro Public Referral Hospital of western Hararghe zone, Oromia regional state, Eastern Ethiopia. Chiro Referral Hospital was established in 1969 and Chiro town is located $326 \mathrm{~km}$ from Addis Ababa in the eastern direction. According to the 2017 G.C town health office plan, the estimated total population of the town is $1,607,922$. Among this population, women of childbearing age account for around 355,833. The expected number of deliveries in the hospital was around 55,795 per year.

Chiro Referral Hospital was the first referral hospital giving emergency management of obstetric and neonatal care service in the western Hararghe zone. The hospital has given services to more than 1.6 million individuals around the area. The services given for pregnant mothers in this hospital are antenatal care, skilled birth attendance, obstetric ultrasound, and other similar services. The hospital has one gynecologist, two integrated 
emergency obstetrics surgeons, and 22 midwives. The study was conducted from July 1 to July 30, 2020.

\section{Study Design and Population}

A facility-based unmatched case-control study was conducted among all pregnant mothers attending antenatal care (ANC) services of Chiro Referral Hospital. Cases (mothers having preeclampsia) were the pregnant mothers who were found to have systolic blood pressure $\geq 140$ $\mathrm{mmHg}$ or diastolic blood pressure $\geq 90 \mathrm{mmHg}$ on two separate readings taken at least 4 hours apart, proteinuria and oedematous after 20 weeks' gestational age, and confirmed by a health professional during ANC service diagnosis. ${ }^{13,17}$ Controls (mothers free of preeclampsia) were the pregnant mother found to have a systolic blood pressure of $<140 \mathrm{mmHg}$ or diastolic blood pressure $<90$ $\mathrm{mmHg}$ on two separate readings and the absence of edematous and proteinuria after 20 weeks' gestational age and confirmed by the health professional during ANC service diagnosis as free of preeclampsia. ${ }^{13,17}$ Thus, the pregnant mothers with preeclampsia and gestational age of greater than 20 weeks were included in the study as cases and pregnant mothers free of preeclampsia and gestational age of greater than 20 weeks were included in the study as controls. Mothers who were critically ill and/or admitted to the intensive care unit and/or who had chronic hypertension were excluded from the study.

\section{Sample Size Determination and Sampling Procedures}

The sample size was determined by the double population proportion formula, using Epi Info version 7 StatCalc function considering a 95\% confidence level, $80 \%$ power, 1:3 case-to-control ratio, and the pregnancy type (twin/ singleton) from the study conducted in Tigray region, Ethiopia. In the study, the odds of preeclampsia were higher among mothers of twin pregnancy than a singleton with a $16.36 \%$ proportion of twin pregnancy among mothers with preeclampsia (cases) and $4.55 \%$ among mothers free of preeclampsia. ${ }^{13}$ Accordingly, the sample size calculated was 73 for cases and 219 controls. By adding a $5 \%$ non-response rate, the final sample size considered for the study was 76 cases and 230 controls, a total of 306 pregnant mothers. To selected study participants preliminary assessment was done to see clients' follow-up of Antenatal care (ANC) services in the hospital from the antenatal log book. As a result of the preliminary assessment, 380 pregnant mothers received antenatal care follow-up in the last month. Among these 380 mothers, 80 of them were found with preeclampsia and the rest were free of preeclampsia. Therefore, the number of cases was almost the calculated sample of cases. Thus, both the cases and controls were selected consecutively. For every one case three controls were selected, as per the above calculation.

\section{Data Collection Process and Quality Control}

Data were collected by questionnaire aided interview which was adapted from different literatures. The questionnaire was first prepared in English and then translated to the local language, Afan Oromo, then back to English to check for consistency by a different language expert. The questionnaire contains socio-demographic characteristics (ie, age, residence, maternal educational, marital status, religion, ethnicity, religion, occupation of mothers, partner's educational status), obstetric and medical disease (ie, gravidity, multiplicity of pregnancy, history of urinary tract infection, previous history of $\mathrm{PIH}$, pregnancy interval, history of abortion, pre-pregnancy oral contraceptive pills use, age at menarche, gestational DM, renal disease, anemia, history of cardiac disease, chronic DM), familial and lifestyle (ie, family history of hypertension, mid-upper arm circumference (MUAC)), and nutritional and behavioral habits (ie, fruits and vegetable consumption, smoking history, alcohol drinking, coffee drinking, physical exercise, and traditional treatment use). For the data collection, one nurse and one midwifery professional who had experience in the maternity unit were recruited and supervised by one public health professional. Two days of intensive training was given to the data collectors and supervisors by the principal investigator on the objective of the study, the methods of data collection, and how to recruit cases and controls.

To assure the quality of data, a pretest was conducted in Chiro Referral Hospital 1 week before the actual data collection time. By taking 5\% of the sample size that was not included in the actual study population, corrections were made based on results of the pretest. Additionally, supervision was provided by the department/unit head of obstetrics, gynecology, and MCH unit ward. Daily, on-site supervision by the supervisor was carried out during the whole period of data collection. At the end of each data collection day, the questionnaires were reviewed and cross-checked for 
completeness, accuracy, and consistency by the investigator, and corrective discussion was undertaken with all the data collectors.

\section{Data Measurement, Processing, and Analysis}

Mothers with preeclampsia were defined as a pregnant mother who was found to have a systolic blood pressure $\geq 140 \mathrm{mmHg}$ or a diastolic blood pressure $\geq 90 \mathrm{mmHg}$ on two separate readings taken at least 4 hours apart with previously normal blood pressure, protein urea, and oedematous after 20 weeks' gestational age and confirmed by the health professional during ANC service diagnosis. ${ }^{13,17}$ A mother free of preeclampsia was a pregnant mother who had systolic blood pressure $<140 \mathrm{mmHg}$ or diastolic blood pressure $<90$ $\mathrm{mmHg}$ on two separate readings and absence of oedematous and proteinuria after 20 weeks' gestational age, as observed and confirmed by the health professionals during ANC service. ${ }^{13,17}$ Pregnancy-induced hypertension was defined as a mother diagnosed with gestational hypertension, preeclampsia, eclampsia, and chronic hypertension with superimposed preeclampsia. Gestational hypertension was systolic blood pressure $\geq 140 \mathrm{mmHg}$ and/or diastolic blood pressure $\geq 90 \mathrm{mmHg}$ measured on two occasions at least 4 hours apart after 20 weeks of gestation in the absence of proteinuria or other systemic symptoms. Eclampsia was characterized by new-onset grand mal seizures in a woman with preeclampsia.

After data completeness was checked manually, it was entered into Epi Info version 7 and exported to SPPS Version 21 for further analysis. A bivariate binary logistic regression analysis was used to assess the association of each independent factor with preeclampsia among pregnant mothers. The variable with a $p$-value less than 0.25 in the bivariate analysis was entered to multiple logistic regression to identify independent factors associated with Preeclampsia. Forward multivariate binary logistic regression was used to identify the variables significantly associated with preeclampsia at a $p$-value less than 0.05 with its odds ratio and $95 \%$ confidence interval. The model

Table I Socio-Demographic Characteristics of Pregnant Mothers Attending ANC Services in Chiro Referral Hospital, Ethiopia, 2020

\begin{tabular}{|c|c|c|c|}
\hline Variable & Category & Cases $(\mathrm{N}=75)$ & Controls $(\mathrm{N}=227)$ \\
\hline Age & $\begin{array}{l}\leq 20 \text { years } \\
20-34 \text { years } \\
\geq 35 \text { years }\end{array}$ & $\begin{array}{l}7(9.3 \%) \\
60(80.0 \%) \\
8(10.7 \%)\end{array}$ & $\begin{array}{l}44(19.4 \%) \\
144(63.4 \%) \\
39(17.2 \%)\end{array}$ \\
\hline Residence & $\begin{array}{l}\text { Urban } \\
\text { Rural }\end{array}$ & $\begin{array}{l}42(56.0 \%) \\
33(44.0 \%)\end{array}$ & $\begin{array}{l}96(42.3 \%) \\
131(57.7 \%)\end{array}$ \\
\hline Marital status & $\begin{array}{l}\text { Married/live together } \\
\text { Never married } \\
\text { Others }\end{array}$ & $\begin{array}{l}58(77.3 \%) \\
9(12.0 \%) \\
8(10.7 \%)\end{array}$ & $\begin{array}{l}189(83.3 \%) \\
22(9.7 \%) \\
16(7.0 \%)\end{array}$ \\
\hline Religion & $\begin{array}{l}\text { Protestant } \\
\text { Orthodox } \\
\text { Muslim } \\
\text { Others }\end{array}$ & $\begin{array}{l}35(46.7 \%) \\
18(24.0 \%) \\
16(21.3 \%) \\
6(8.0 \%)\end{array}$ & $\begin{array}{l}103(45.4 \%) \\
65(28.6 \%) \\
47(20.7 \%) \\
12(5.3 \%)\end{array}$ \\
\hline Ethnicity & $\begin{array}{l}\text { Oromo } \\
\text { Amhara } \\
\text { Others }\end{array}$ & $\begin{array}{l}53(70.7 \%) \\
15(20.0 \%) \\
7(9.3 \%)\end{array}$ & $\begin{array}{l}\text { I50 (67.2\%) } \\
57(25.1 \%) \\
20(8.8 \%)\end{array}$ \\
\hline Mothers' Educational level & $\begin{array}{l}\text { No formal education } \\
\text { Formal education }\end{array}$ & $\begin{array}{l}31(41.3 \%) \\
44(58.7 \%)\end{array}$ & $\begin{array}{l}53(23.3 \%) \\
174(76.7 \%)\end{array}$ \\
\hline Occupation & $\begin{array}{l}\text { Housewife } \\
\text { Government } \\
\text { Self and private business } \\
\text { Others }\end{array}$ & $\begin{array}{l}32(42.7 \%) \\
16(21.3 \%) \\
22(29.3 \%) \\
5(6.7 \%)\end{array}$ & $\begin{array}{l}\text { III (47.4\%) } \\
51(22.5 \%) \\
55(24.2 \%) \\
10(4.4 \%)\end{array}$ \\
\hline Husbands` educational level & $\begin{array}{l}\text { No formal education } \\
\text { Formal education }\end{array}$ & $\begin{array}{l}12(16.0 \%) \\
63(84.0 \%)\end{array}$ & $\begin{array}{l}35(15.4 \%) \\
192(84.6 \%)\end{array}$ \\
\hline
\end{tabular}


fitness was tested by Hosmer Lemeshow's goodness fit test which reported a $p$-value greater than 0.05 . The result was presented in narrations, tables, and graphs.

\section{Results}

\section{Socio-Demographic Characteristics}

Among the 76 cases and 230 controls of pregnant mothers planned to be included in the study from Chiro Referral Hospital, 75 of the cases and 227 of the controls participated in the study, yielding a response rate of $98.7 \%$ for the groups. The mean ages of cases and controls were $26.04( \pm 4.82)$ and $26.30( \pm 4.65)$ years, respectively.

More than half $(56.0 \%)$ of the cases and 96 (42.3\%) controls were from urban residences. Regarding the ethnicity of respondents, fifty-three $(70.7 \%)$ of the cases and $150(66.1 \%)$ of controls belonged to the Oromo ethnic group. The dominant religion of the study participants was protestant, at $35(46.7 \%)$ cases and 103 (45.4\%) controls. The majority of respondents, 68 (77.3\%) cases and $189(83.3 \%)$ controls, were married and in union with their partners. Forty-four (58.7\%) cases and 174 (76.7\%) controls had formal education. With regards to their occupation, $32(42.7 \%)$ of the cases and 111 (48.9\%) of the controls were housewives. Most of the husbands, of 63 $(84.0 \%)$ cases and $192(84.6 \%)$ controls, had formal education (Table 1).

\section{Obstetric and Medical-Related Factors}

Nearly three-quarters $(74.7 \%)$ of the cases and 117 $(51.5 \%)$ of the controls were a multi gravid mother, and $60(80.0 \%)$ cases and $199(87.7 \%)$ controls had a singleton pregnancy.

Regarding gestational DM, 72 (96.0\%) cases and 209 (92.1\%) controls did not have gestational DM during this index pregnancy. Nearly two-thirds $(65.3 \%)$ of the cases and $133(58.6 \%)$ of the controls had not used combined oral contraceptives preceding this pregnancy index. The average age at menarche was 15 years; $53(70.7 \%)$ of the cases and $147(64.8 \%)$ of the controls saw their first menstruation at age less than 15 years. In terms of the previous history of hypertensive disorder of pregnancy, 23 $(30.7 \%)$ cases and $29(12.8 \%)$ controls had a history of hypertensive disorders of pregnancy. In addition to this, 32 $(62.7 \%)$ cases and $90(55.6 \%)$ controls had pregnancy intervals of fewer than 5 years. About $21.3 \%$ of the cases and $18.5 \%$ of the controls had a history of abortion and, of these, six (37.5\%) of the cases and $11(26.2 \%)$ of the controls had an abortion more than once.

Sixty-six (88.0\%) f cases and 208 (91.6\%) controls had no chronic DM. Among study participants, only one of the cases and nine of the controls had a cardiac problem. Sixteen $(21.3 \%)$ of the cases and $46(20.3 \%)$ of the controls had renal disease and $30(40.0 \%)$ cases and 46 (20.3\%) controls had UTI/pyelonephritis during this index pregnancy. Only 12 cases and controls had hemoglobin below normal measurement (Table 2).

Table 2 Obstetrics and Medical History of Pregnant Mothers Attending ANC Services in Chiro Referral Hospital, Ethiopia, 2020

\begin{tabular}{|c|c|c|c|}
\hline Variables & Category & $\begin{array}{l}\text { Cases } \\
(\mathrm{N}=75)\end{array}$ & $\begin{array}{l}\text { Controls } \\
(\mathrm{N}=227)\end{array}$ \\
\hline \multirow[t]{2}{*}{ Gravidity } & Prim gravid & 19 (25.3\%) & II 0 (48.5\%) \\
\hline & Multi gravid & 56 (74.7\%) & 117 (5I.5\%) \\
\hline \multirow[t]{2}{*}{ Type of pregnancy } & Single & $60(80.0 \%)$ & 199 (87.7\%) \\
\hline & Twin & I5 (20.0\%) & $28(12.3 \%)$ \\
\hline \multirow[t]{2}{*}{ Gestational DM } & Yes & $3(4.0 \%)$ & $18(7.0 \%)$ \\
\hline & No & $72(96.0)$ & 209 (92.1\%) \\
\hline \multirow[t]{2}{*}{$\mathrm{COC}$ use } & Yes & 26 (34.7\%) & 94 (4I.4\%) \\
\hline & No & 49 (65.3\%) & I 33 (58.6\%) \\
\hline \multirow[t]{2}{*}{ Age at menarche } & $<15$ years & 53 (70.7\%) & 147 (64.8\%) \\
\hline & $\geq 15$ years & $22(29.3 \%)$ & 80 (35.2\%) \\
\hline \multirow{2}{*}{$\begin{array}{l}\text { History of PIH } \\
(n=2 \mid 4)\end{array}$} & Yes & $12(28.5 \%)$ & $63(38.7 \%)$ \\
\hline & No & 39 (28.1\%) & $100(61.3 \%)$ \\
\hline \multirow{2}{*}{$\begin{array}{l}\text { Pregnancy interval } \\
(n=2 \mid 4)\end{array}$} & $\leq 5$ years & $32(62.7 \%)$ & 90 (55.2\%) \\
\hline & $>5$ years & 19 (37.3\%) & 73 (44.8\%) \\
\hline \multirow[t]{2}{*}{ History of abortion } & Yes & $16(21.3 \%)$ & $42(18.5 \%)$ \\
\hline & No & 59 (78.7\%) & 185 (8I.5\%) \\
\hline \multirow{2}{*}{$\begin{array}{l}\text { How many abortions } \\
(n=58)\end{array}$} & Once & 10 (62.5\%) & 31 (73.8\%) \\
\hline & >Once & $6(37.5 \%)$ & II (26.2\%) \\
\hline \multirow[t]{2}{*}{ Chronic DM } & Yes & $9(12.0 \%)$ & $19(8.4 \%)$ \\
\hline & No & $66(88.0 \%)$ & 208 (91.6\%) \\
\hline \multirow[t]{2}{*}{ Cardiac disease } & Yes & I (I.3) & $9(4.0 \%)$ \\
\hline & No & 74 (98.7\%) & $218(96.0 \%)$ \\
\hline \multirow[t]{2}{*}{ Renal disease } & Yes & $16(21.3 \%)$ & 46 (20.3\%) \\
\hline & No & 59 (78.7\%) & I8I (79.7\%) \\
\hline \multirow[t]{2}{*}{ UTI/pyelonephritis } & Yes & 30 (40.0\%) & $68(30.0 \%)$ \\
\hline & No & 45 (70.0\%) & I 59 (70.0\%) \\
\hline \multirow[t]{2}{*}{ Hemoglobin level } & $\geq 11 \mathrm{mh} / \mathrm{dL}$ & $12(16.0 \%)$ & $12(5.3 \%)$ \\
\hline & $<11 \mathrm{mg} / \mathrm{dL}$ & $63(84.0 \%)$ & 215 (94.7\%) \\
\hline
\end{tabular}




\section{Familial and Lifestyle Related Factors}

Twelve $(16.0 \%)$ of the cases and $80(35.2 \%)$ of the controls had a family history of hypertension. Mid-upper arm circumference of the mothers was categorized as below and above mean $(\leq 22.2$ and $>22.2 \mathrm{~cm})$ and more than half of the cases and controls had MUAC $\leq 22.2 \mathrm{~cm}$.

Among the study participants, the majority, 67 (89.3\%) cases and $212(93.4 \%)$ controls, did not use any type of traditional treatment. Sixty-three $(84.0 \%)$ cases and 180 (79.3\%) controls had drunk coffee during their pregnancy index. Among those who drank coffee, the greater than $90 \%$ of cases and controls drank coffee at home and outside. Thirty-three (52.4\%) of the cases and 98 (54.4\%) of the controls drank less than three cups at each episode at home and outside. Only three cases and nine controls had a smoking history. Most, 56 (74.7\%) cases and 186 $(81.9 \%)$ controls, did not have a history of alcohol consumption, while $61(81.3 \%)$ cases and 166 (73.1\%) controls did not adhere to physical exercise.
With regards of nutritional/dietary habits of participants, only $14(18.7 \%)$ of the cases and $28(12.3 \%)$ of the controls consumed fruit in their diet more than 2-4 times a week and only 8eight $(10.7 \%)$ of the cases and 30 $(13.2 \%)$ of the controls consumed vegetables (Table 3 ).

\section{Determinants of Preeclampsia Among Pregnant Mothers}

In bivariate binary logistic regression analysis, the age of mothers, place of residence, maternal education, family history of hypertension, mid-upper arm circumference of respondent, alcohol consumption history, physical exercise during pregnancy, gravidity of mothers, numbers of birth in the current pregnancy, previous history of hypertensive disorders of pregnancy, UTI/pyelonephritis, hemoglobin level, and fruit consumption history fulfilled the criteria and were the potential candidate variables for multiple logistic regression. However, in multivariate binary logistic regression analysis age, residences, family history of

Table 3 Familial and Lifestyle Related Factors of Pregnant Mothers Attending ANC Services in the Chiro Referral Hospital, Ethiopia, 2020

\begin{tabular}{|c|c|c|c|}
\hline Variables & Category & Cases $(\mathbf{N}=75)$ & Controls $(\mathrm{N}=227)$ \\
\hline \multirow[t]{2}{*}{ Family history of hypertension } & Yes & $12(16.0 \%)$ & $80(35.2 \%)$ \\
\hline & No & $63(84.0 \%)$ & I 47 (64.8\%) \\
\hline \multirow[t]{2}{*}{ MUAC } & $\leq 22.2 \mathrm{~cm}$ & 38 (50.7\%) & I 37 (60.4\%) \\
\hline & $>22.2 \mathrm{~cm}$ & 37 (49.3\%) & $90(39.6 \%)$ \\
\hline \multirow[t]{2}{*}{ Smoking history } & Yes & $3(4.0 \%)$ & $9(4.0 \%)$ \\
\hline & No & $72(96.0)$ & $218(96.0 \%)$ \\
\hline \multirow[t]{2}{*}{ Traditional txt use } & Yes & $8(10.7 \%)$ & $15(6.6 \%)$ \\
\hline & No & 67 (89.3\%) & $212(93.4 \%)$ \\
\hline \multirow[t]{2}{*}{ Coffee use } & Yes & $63(84.0 \%)$ & I 80 (79.3\%) \\
\hline & No & $12(16.0 \%)$ & 47 (20.7\%) \\
\hline Frequency of coffee use $(\mathrm{N}=243)$ & $<1$ day & 59 (93.7\%) & $162(90.0 \%)$ \\
\hline \multirow[t]{2}{*}{ Volume of coffee use $(\mathrm{N}=243)$} & $<3$ cups & $33(52.4 \%)$ & $98(54.4 \%)$ \\
\hline & $\geq 3$ cups & $30(47.6 \%)$ & $82(45.6 \%)$ \\
\hline \multirow[t]{2}{*}{ Alcohol intake } & Yes & $19(25.3 \%)$ & $4 I(18.1 \%)$ \\
\hline & No & $56(74.7 \%)$ & $186(81.9 \%)$ \\
\hline \multirow[t]{2}{*}{ Physical exercise } & Yes & $14(18.7 \%)$ & $6 \mathrm{I}(26.9 \%)$ \\
\hline & No & 61 (81.3\%) & $166(73.1 \%)$ \\
\hline \multirow[t]{2}{*}{ Fruit consumer } & Yes & 14 (I8.7\%) & $28(12.3 \%)$ \\
\hline & No & 61 (8I.3\%) & 199 (89.7\%) \\
\hline \multirow[t]{2}{*}{ Vegetable consumer } & Yes & $8(10.7 \%)$ & 30 (I3.2\%) \\
\hline & No & $67(89.3 \%)$ & 197 (74.6\%) \\
\hline
\end{tabular}


hypertension, gravidity of mothers, and fruit consumption were significantly associated with preeclampsia.

Accordingly, the odds of developing preeclampsia were 4-times higher among mothers aged $\geq 35$ years compared to mothers in the age group 20-34 years ( $\mathrm{AOR}=4.01 ; 95 \% \mathrm{CI}=1.25-12.80)$ while it was more than 3-times higher among mothers living in rural residents compared to those residing in urban areas (AOR=3.30; 95\% CI $=1.50-7.26$ ).

The odds of developing preeclampsia were 3.25-times higher among pregnant mothers having a family history of hypertension than those who did not have a family history of hypertension $(\mathrm{AOR}=3.25 ; 95 \% \mathrm{CI}=1.36-7.73)$.
Prim gravid mothers had above 3-times higher odds of developing preeclampsia than multi gravid mothers (AOR=3.71, 95\% CI=1.49-9.22).

Mothers who consumed fruits in their dietary habits were about $62 \%$ less likely to develop preeclampsia than those who did not consume fruits $(\mathrm{AOR}=0.38 ; 95 \%$ $\mathrm{CI}=0.15-0.98$ ) (Table 4).

\section{Discussion}

Recognizing determinants factors that affect preeclampsia in pregnant women had supreme importance to reducing maternal and fetal/neonatal mortality and morbidity. This study revealed that the odds of developing preeclampsia

Table 4 Determinants of Preeclampsia Among Pregnant Mothers Attending ANC Services in Chiro Referral Hospital, Ethiopia, 2020

\begin{tabular}{|c|c|c|c|c|c|c|}
\hline Variables & Category & Controls $(\mathrm{N}=\mathbf{2 2 7})$ & Cases $(\mathbf{N}=75)$ & COR $(95 \% \mathrm{Cl})$ & AOR $(95 \% \mathrm{Cl})$ & $p$-value \\
\hline Age & $\begin{array}{l}<20 \text { year } \\
20-34 \text { year } \\
\geq 35 \text { year }\end{array}$ & $\begin{array}{l}44(19.4 \%) \\
144(63.4 \%) \\
39(17.2 \%)\end{array}$ & $\begin{array}{l}7(9.3 \%) \\
60(80.0 \%) \\
8(10.7 \%)\end{array}$ & $\begin{array}{l}2.62(1.12-6 \mid 4) \\
1 \\
2.03(0.90-4.60)\end{array}$ & $\begin{array}{l}2.50(0.88-7.00) \\
4.00(1.25-12.80)\end{array}$ & $\begin{array}{l}0.084 \\
0.019 *\end{array}$ \\
\hline Residence & $\begin{array}{l}\text { Urban } \\
\text { Rural }\end{array}$ & $\begin{array}{l}96(42.3 \%) \\
|3|(57.7 \%)\end{array}$ & $\begin{array}{l}42(56.0 \%) \\
33(44.0 \%)\end{array}$ & $\begin{array}{l}\text { I } \\
1.73(1.02-2.94)\end{array}$ & $3.30(1.50-7.26)$ & $0.003 *$ \\
\hline Maternal educational status & $\begin{array}{l}\text { Illiterate } \\
\text { Literate }\end{array}$ & $\begin{array}{l}53(23.3 \%) \\
174(76.7 \%)\end{array}$ & $\begin{array}{l}31 \text { (4I.3\%) } \\
44(58.7 \%)\end{array}$ & $\begin{array}{l}0.43(0.25-0.75) \\
\mathrm{I}\end{array}$ & $0.14(0.06-0.33)$ & 0.067 \\
\hline Family history of hypertension & $\begin{array}{l}\text { Yes } \\
\text { No } \\
\geq \text { I day }\end{array}$ & $\begin{array}{l}80(35.2 \%) \\
147(64.8 \%) \\
4(6.3 \%)\end{array}$ & $\begin{array}{l}12(16.0 \%) \\
63(84.0 \%) \\
18(10.0 \%)\end{array}$ & $\begin{array}{l}2.86(1.45-5.61) \\
I\end{array}$ & $3.25(1.36-7.73)$ & $0.008^{*}$ \\
\hline MUAC & $\begin{array}{l}\leq 22.2 \\
>22.2\end{array}$ & $\begin{array}{l}137(60.4 \%) \\
90(39.6 \%)\end{array}$ & $\begin{array}{l}38(50.7 \%) \\
37(49.3 \%)\end{array}$ & $\begin{array}{l}\text { I } \\
0.68(0.40-1.14)\end{array}$ & $0.63(0.29-1.39)$ & 0.235 \\
\hline Physical exercise & $\begin{array}{l}\text { Yes } \\
\text { No }\end{array}$ & $\begin{array}{l}61(26.9 \%) \\
166(73.1 \%)\end{array}$ & $\begin{array}{l}14(18.7 \%) \\
61(81.3 \%)\end{array}$ & $\begin{array}{l}\text { I.60 (0.84-3.67) } \\
\mathrm{I}\end{array}$ & $1.46(0.60-3.52)$ & 0.405 \\
\hline Alcohol use & $\begin{array}{l}\text { Yes } \\
\text { No }\end{array}$ & $\begin{array}{l}41(18.1 \%) \\
186(81.9 \%)\end{array}$ & $\begin{array}{l}19(25.3 \%) \\
56(74.7 \%)\end{array}$ & $\begin{array}{l}0.65(0.34-1.21) \\
I\end{array}$ & $0.45(0.19-1.06)$ & 0.067 \\
\hline Gravidity & $\begin{array}{l}\text { Prim gravid } \\
\text { Multi gravida }\end{array}$ & $\begin{array}{l}110(48.5 \%) \\
117(51.5 \%)\end{array}$ & $\begin{array}{l}19(25.3 \%) \\
56(74.7 \%)\end{array}$ & $\begin{array}{l}2.77(1.55-4.96) \\
I\end{array}$ & $3.7 \mathrm{I}(\mathrm{I} .49-9.22)$ & $0.005^{*}$ \\
\hline Multiplicity of pregnancy & $\begin{array}{l}\text { Single } \\
\text { Twin }\end{array}$ & $\begin{array}{l}199(87.7 \%) \\
28(12.3 \%)\end{array}$ & $\begin{array}{l}60(80.0 \%) \\
15(20.0 \%)\end{array}$ & $\begin{array}{l}\mathrm{I} \\
0.56(0.28-I .12)\end{array}$ & $0.48(0.18-1.29)$ & 0.144 \\
\hline History of PIH $(n=2 \mid 4)$ & $\begin{array}{l}\text { Yes } \\
\text { No }\end{array}$ & $\begin{array}{l}63(38.7 \%) \\
100(61.3 \%)\end{array}$ & $\begin{array}{l}12(28.5 \%) \\
39(28.1 \%)\end{array}$ & $\begin{array}{l}2.04(1.00-4.20) \\
1\end{array}$ & $1.66(0.72-3.82)$ & 0.232 \\
\hline UTI/pyelonephritis & $\begin{array}{l}\text { Yes } \\
\text { No }\end{array}$ & $\begin{array}{l}68(30.0 \%) \\
159(70.0 \%)\end{array}$ & $\begin{array}{l}30(40.0 \%) \\
45(70.0 \%)\end{array}$ & $\begin{array}{l}0.64(0.37-1.10) \\
I\end{array}$ & $0.55(0.26-1.19)$ & 0.129 \\
\hline Hemoglobin level & $\begin{array}{l}\geq 11 \mathrm{mh} / \mathrm{dL} \\
<11 \mathrm{mg} / \mathrm{dL}\end{array}$ & $\begin{array}{l}12(5.3 \%) \\
215(94.7 \%)\end{array}$ & $\begin{array}{l}12(16.0 \%) \\
63(84.0 \%)\end{array}$ & $\begin{array}{l}0.29(0.13-0.68) \\
1\end{array}$ & $0.87(0.20-3.75)$ & 0.885 \\
\hline Fruit consumption & $\begin{array}{l}\text { Yes } \\
\text { No }\end{array}$ & $\begin{array}{l}28(12.3 \%) \\
199(89.7 \%)\end{array}$ & $\begin{array}{l}14(18.7) \\
61(81.3)\end{array}$ & $\begin{array}{l}0.61(0.30-1.24) \\
1\end{array}$ & $0.38(0.15-0.98)$ & $0.046^{*}$ \\
\hline
\end{tabular}

Note: *Significant factors. 
were almost 4-times higher among advanced maternal age ( $\geq 35$ years) as compared to maternal age between $20-34$ years. This finding has been supported by different works of literature in different countries. Studies in Washington, ${ }^{18}$ Hohoe municipality hospitals of Ghana, ${ }^{19}$ Tehran, Iran, ${ }^{20}$ and Dirashe woreda, Ethiopia ${ }^{21}$ supported the current finding. The possible reason may be due to the methodological similarity of studies. Practically this finding confirmed the evidence of biological plausibility as maternal age increases the oxidative stress of mothers elevated, as the result, it adversely affects the relaxation of endometrial during pregnancy. This could be because cardiac output increases as the age of the pregnant mothers advances, which in turn results in preeclampsia. ${ }^{22}$

In this study, mothers living in a rural areas had more than 3-times higher odds of developing preeclampsia than urban residents. The finding is in line with studies conducted in Tigray, a hospital based study, ${ }^{13}$ Cameroon, ${ }^{23}$ and an epidemiological study among pregnant mothers in Cairo, Egypt. ${ }^{24}$ This might be due to rural resident mothers having less consumption of fruits and vegetables which are protective effects for preeclampsia; even though productions were common in rural residents. Another possible reason was mothers from rural areas book ANC later in pregnancy and delay health-seeking behavior, as a result they are late in recognizing preeclampsia. This delay in healthcare-seeking behavior could be due to family and local cultural influences, and rural residents' give great value to their cultures.

In this study, the odds of developing preeclampsia were more than 3-times higher among mothers having a family history of hypertension as compared to those mothers who had no family history of hypertension. This finding is congruent with studies conducted in Ghana, Hohoe municipality hospital, ${ }^{19}$ in Bangkok, Thailand, ${ }^{25}$ in Kombolcha, Ethiopia, ${ }^{12}$ and Bahir Dar town, Ethiopia ${ }^{26}$ which pointed out that having a family history of hypertension was a risk factor for the current development of preeclampsia. The similarity of this finding might be due to a similar design conducted on the population recruited from facilities. This was backed up by biophysical evidence that preeclampsia was a familial disease. ${ }^{27}$

The current study revealed that the odds of developing preeclampsia were nearly 4-times higher among prim gravid mothers than multi gravid. This result is comparable with different studies from Colombia, ${ }^{28}$ Jahun Hospital, Nigeria, ${ }^{29}$ and Zewditu Hospital, and Gandhi Memorial Hospital, ${ }^{17}$ and Dirashe woreda, Ethiopia. ${ }^{21}$ This could be due to immunological incompetence that happened during this first pregnancy between fetoplacental and maternal tissue. Hypertensive disorders of pregnancy are generally known as a disease of the first pregnancy.

The study revealed that high fruit consumer mothers were protected against preeclampsia. Fruit consumer mothers are about $68 \%$ less likely to develop preeclampsia as compared to their counterparts. This finding was inconsistent with previous studies conducted in Bahir Dar, Ethiopia, ${ }^{26}$ the Tigray region, ${ }^{13}$ and Cairo, Egypt. ${ }^{24}$ On the other hand, this finding was supplemented by a systematic review and meta-analysis study where the use of calcium, ${ }^{15,30}$ vitamin $\mathrm{D},{ }^{30,31}$ folic acid, and resveratrol during pregnancy was found to be a protective effect for hypertensive disorders of pregnancy. ${ }^{30}$ Fruits are rich in calcium and folic acid, vitamin $\mathrm{D}$, and minerals which play an antioxidant role which could in turn help in the prevention of hypertensive disorders of pregnancy.

\section{Conclusions and Recommendations}

In conclusion, pregnant mothers at higher age ( $>35$ years), rural residents, those having a family history of hypertension and prim gravidity were at high risk to have preeclampsia. Mothers who consume fruits in their diet were regularly at less risk to have preeclampsia. Thus, healthcare providers shall give priority to pregnant mothers in the older age category, primigravida, those who have a history of a family with hypertension, and from rural residences to diagnose the diseases as early as possible. Additionally, advising pregnant mothers attending antenatal care to consume fruits as early as possible in their daily diet reduces the risk of preeclampsia.

\section{Abbreviations}

ANC, antenatal care; AOR, adjusted odds ratio; CI, confidence interval; $\mathrm{COC}$, combined oral contraceptive; COR, crude odds ratio; DM, diabetes mellitus; G.C, Gregorian calendar; $\mathrm{MCH}$, maternal and child health; MUAC, midupper arm circumference; PIH, pregnancy-induced hypertension; UTI, urinary tract infection.

\section{Ethics and Consent to Participate}

A letter of ethical clearance was obtained from the Institutional Review Board (IRB) of Adama General Hospital and Medical College. A permission letter was attained from the medical director of each facility for getting necessary information; Record reviewing and interviewing concerned individuals residing in Hospital. The aim of the study was explained briefly to the mothers and confidentiality was assured. 
Finally, oral informed consent was obtained from each mother to proceed with data collection after approval of the IRB of the Adama General Hospital and Medical College approved verbal informed consent. The study was conducted in accordance with the Declaration of Helsinki.

\section{Acknowledgment}

We would like to acknowledge Adama General Hospital and Medical College, data collectors and supervisors, study participants, friends, and family members for their support.

\section{Author Contributions}

All authors (Fikre Hambamo Katore, Abenet Menene Gurara, and Teresa Kisi Beyen) made substantial contributions in the conception, design, analysis, and interpretation of data as well as took part in drafting the article, revising it critically for important intellectual content; agreed to submit to the current journal; gave final approval of the version to be published; and agree to be accountable for all aspects of the work.

\section{Disclosure}

The authors declared that there were no competing interests in this work.

\section{References}

1. Abalos E, Cuesta C, Carroli G, et al. Pre-eclampsia, eclampsia and adverse maternal and perinatal outcomes: a secondary analysis of the World Health Organization Multicountry Survey on Maternal and Newborn Health. BJOG. 2014;121(suppl. 1):14-24. doi:10.1111/ 1471-0528.12629

2. National institute for health and clinical excellence (NICE). Hypertension in pregnancy: diagnosis and management [Internet]; 2019. Available from: https://www.nice.org.uk/guidance/ng133. Accessed November 16, 2021.

3. Kintiraki E, Papakatsika S, Kotronis G, Goulis DG, Kotsis V. Review, pregnancy-induced hypertension. Hormones. 2015;14(2):211-223. doi:10.14310/horm.2002.1582

4. Lowe SA, Bowyer L, Lust K, et al. The SOMANZ guideline for the management of hypertensive disorders of pregnancy 2014. Aust N Z J Obstet Gynaecol. 2015;55(5):11-16. doi:10.1111/ajo.12253

5. Working Group on High Blood Pressure in Pregnancy. Report of the National High Blood Pressure Education Program Working Group on High Blood Pressure in Pregnancy. Am J Obs Gynecol. 2000;183(1): S1-S22. doi:10.1067/mob.2000.107928

6. Adu-Bonsaffoh K, Ntumy MY, Obed SA, Seffah JD. Prevalence of hypertensive disorders in pregnancy at Korle-Bu teaching hospital in Ghana. J Gynecol Neonatal Biol. 2017;3(1):8-13.

7. Osungbade KO, Ige OK. Public health perspectives of preeclampsia in developing countries: implication for health system strengthening. Hindawi J Pregnancy. 2011;2011:1-6. doi:10.1155/2011/481095

8. Muti M, Tshimanga M, Notion GT, Bangure D, Chonzi P. Prevalence of pregnancy induced hypertension and pregnancy outcomes among women seeking maternity services in Harare, Zimbabwe. BMC Cardiovasc Disord. 2015;15(111):1-8. doi:10.1186/s12872-0150110-5
9. Central Statistical Agency (CSA) [Ethiopia] and ICF. Ethiopia Demographic and Health Survey 2016. Addis Ababa, Ethiopia, and Rockville, Maryland, USA: CSA and ICF; 2016.

10. Berhan Y, Berhan A. Review of causes of maternal morbidity and mortality in Ethiopia. Ethiop J Health Sci. 2014. doi:10.4314/ejhs. v24i1.3S

11. Seyom E, Abera M, Tesfaye M, Fentahun N. Maternal and fetal outcome of pregnancy related hypertension in Mettu Karl referral hospital. J Ovarian Res. 2015;8(10):1-7. doi:10.1186/s13048-0150135-5

12. Temesgen MA. Factors associated with hypertensive disorder of pregnancy in Kombolcha. Clin Mother Child Health. 2017;14 (4):1-5. doi:10.4172/2090-7214.1000274

13. Kahsay HB, Gashe FE, Ayele WM, Ayele WM. Risk factors for hypertensive disorders of pregnancy among mothers in Tigray region, Ethiopia: matched case-control study. BMC Pregnancy Childbirth. 2018;18(482):1-10. doi:10.1186/s12884-018-2106-5

14. WHO. WHO recommendations; Prevention and treatment of pre-eclampsia and eclampsia. Geneva; Swezerland; 2011.

15. Imdad A, Jabeen A, Bhutta ZA. Role of calcium supplementation during pregnancy in reducing risk of developing gestational hypertensive disorders: a meta- analysis of studies from developing countries. BMC Public Health. 2011;11(suppl 3):1-13. doi:10.1186/ 1471-2458-11-S3-S1

16. English FA, Kenny LC, McCarthy FP. Risk factors and effective management of preeclampsia. Integr Blood Press Control. 2015;8:7-12.

17. Grum T, Seifu A, Abay M, Angesom T, Tsegay L. Determinants of pre-eclampsia/Eclampsia among women attending delivery services in selected public hospitals of Addis Ababa, Ethiopia: a case control study. BMC Pregnancy Childbirth. 2017;17(307):1-7. doi:10.1186/ s12884-017-1507-1

18. Coghill AE, Hansen S, Littman AJ. Risk factors for eclampsia: a population-based study in Washington State, 1987 - 2007. Am J Obs Gynecol. 2011;205(553):e1-7. doi:10.1016/j.ajog.2011.06.079

19. Jones L, Takramah W, Owusu R, et al. Risk factors associated with pregnancy induced hypertension in the Hohoe Municipality of Ghana. J Prev Med Healthcare. 2017;1(3):1-8.

20. Kashanian M, Baradaran HR, Bahasadri S, Alimohammadi R. Risk factors for Pre-Eclampsia: a study in Tehran. Arch Iran Med. 2011;14 (9):412-415.

21. Ayele G, Lemma S, Agedew E. Factors associated with hypertension during pregnancy in Derashie Woreda South Ethiopia, case-control study; maternal health project officer in save the children in Segen People Area Zone, Southern Nation. Qual Prim Care. 2016;24 (5):207-213.

22. Verma MK, Kapoor P, Yadav R, Manohar RK. Risk factor assessment for pre-eclampsia: a case control study. Int $J$ Med Public Health. 2017;7(3):172-177. doi:10.5530/ijmedph.2017.3.35

23. Tebeu PM, Foumane P, Mbu R, Fosso G, Biyaga PT, Fomulu JN. Risk factors for hypertensive disorders in pregnancy: a report from the Maroua Regional Hospital, Cameroon. J Reprod Infertil. 2011;12 (3):227-234

24. El-Moselhy EA, Khalifa HO, Amer MS, Mohammad KI, Abd El-Aal HM. Risk factors and impacts of pre-eclampsia: an epidemiological study among pregnant mothers in Cairo, Egypt. J Am Sci. 2011;7 (5):311-323.

25. Aksornphusitaphong A, Phupong V. Risk factors of early and late onset pre-eclampsia. J Obstet Gynecol Res. 2013;39(3):627-631. doi:10.1111/j.1447-0756.2012.02010.x

26. Endeshaw M, Ambaw F, Aragaw A, Ayalew A. Effect of maternal nutrition and dietary habits on preeclampsia: a case-control study. Int J Clin Med. 2014;5:1405-14016. doi:10.4236/ijcm.2014.521179

27. Chesley LC, Annitto JE, Cosgrov RA. The familial factor in toxemia of pregnancy. Am J Obstet Gynecol. 1968;32(3):303-311. 
28. Reyes LM, Garc1'a RG, Ruiz SL, et al. Risk factors for preeclampsia in women from Colombia: a case-control study. PLoS One. 2012;7 (7):e41622. doi:10.1371/journal.pone.0041622

29. Guerrier G, Oluyide B, Keramarou M, Grais RF. Factors associated with severe preeclampsia and eclampsia in Jahun, Nigeria: case control study. Int J Womens Health. 2013;5:509-5013. doi:10.2147/ IJWH.S47056
30. Fogacci S, Fogacci F, Cicero AFG. Nutraceuticals and hypertensive disorders in pregnancy: the available clinical evidence. Nutrients. 2020;12(2):378-388. doi:10.3390/nu12020378

31. Fogacci S, Fogacci F, Banach M, et al. Vitamin D supplementation and incident preeclampsia: a systematic review and meta-analysis of randomized clinical trials. Clin Nutr. 2020;39(6):1742-1752. doi:10.1016/j.clnu.2019.08.015

\section{Publish your work in this journal}

Integrated Blood Pressure Control is an international, peer-reviewed open-access journal focusing on the integrated approach to managing hypertension and risk reduction. Treating the patient and comorbidities together with diet and lifestyle modification and optimizing healthcare resources through a multidisciplinary team approach constitute key features of the journal. This journal is indexed on

Submit your manuscript here: https://www.dovepress.com/integrated-blood-pressure-control-journa
American Chemical Society's Chemical Abstracts Service (CAS). The manuscript management system is completely online and includes a very quick and fair peer-review system, which is all easy to use. Visit http://www.dovepress.com/testimonials.php to read real quotes from published authors. 